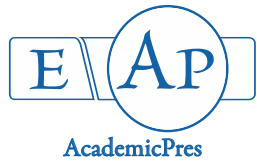

\title{
Biocontrol of Sclerotium rolfsii in Groundnut by Using Microbial Inoculants
}

\author{
Khirood DOLEY*, Mayura DUDHANE, Mahesh BORDE \\ Savitribai Phule Pune University, Department of Botany, Maharashtra, 411007 Pune, \\ India; khirood_doleys@yahoo.com (*corresponding author)
}

\begin{abstract}
Sclerotium rolfsii (Sacc.) is the causal agent of stem-rot in groundnut (Arachis hypogaea L.)crop. With the increase in demand for the groundnut, control of stem-rot efficiently by microbial strains is fast becoming inevitable as the conventional system of chemicals is degrading our ecosystem. This investigation here emphasizes on inoculation of arbuscular mycorrhizal fungi (AMF) and Trichoderma species for growth achievement and disease control. The present investigation showed that these microbial strains were found to be worth applying as they stimulated growth and decreased harmful effects of $S$. rolfsii (cv. 'Western-51'). The increased biochemical parameters and antioxidant activities also indicated their defence related activities in groundnut plants. In spite of positive attributes meted out by these microbial strains towards groundnut crop, the interaction among AM fungi and Trichoderma species seemed to be less co-operative between each other which were noted when mycorrhizal dependency and percent root colonization were observed. However, in summary more practical application of low-input AM fungi along with Trichoderma species may be needed for the advancement of modern agricultural systems.
\end{abstract}

Keywords: arbuscular mycorrhizal fungi, disease control, groundnut, stem-rot, Trichoderma

\section{Introduction}

In the present scenario due to already delimiting natural resources, it will be a monumental task for the humankind ahead to feed and look for alternatives for their existence. Moreover, the rate of population growth with increasing pollution is becoming a matter of great concern for the countries all over the world. For sustaining life on the earth, food security seems to be a priority which can be achieved only by increasing the agricultural production. But, at the same time the utilization of harmful chemical fertilizers and pesticides should be discouraged due to its environmental implications and health concerns of humans. The implication of biological control will not only minimize dependence on chemicals but also safeguards our environment. Several micro-organisms exist in rhizospheric soil associated with plant roots which confers many beneficial attributes in growth and health of plants. These micro-organisms are known to acts synergistically by several modes of mechanisms (Alabouvette et al., 2009).

In this regard, the symbiotic rhizospheric association of arbuscular mycorrhizal fungi (AMF) and Trichoderma species that exists in microbial forms has been accepted as potential for low-input solution to promote growth as well as in disease resistance (Bhale et al., 2013; Cameroon et al., 2013;
Mukherjee et al., 2014). As it is already known that over $90 \%$ of terrestrial plants are associated with mycorrhiza in which mycorrhizal species get hold of products from photosynthesis $(25 \%)$ and contribute almost $80 \%$ of nutrients to host plants (Ene et al., 2010; Meyer et al., 2010; Smith and Smith, 2012). In particular, the rhizospheric symbiont AM fungi not only increases the nutrient uptake efficiency of most agricultural crops but are also known to increase soil structure and suppress diseases (Ziedan et al., 2011; Verbruggen et al., 2013). The saprophytic symbiont Trichoderma species are also associated with the plant roots which help in growth promotion and inhibition of important plant diseases (Hohmann et al., 2011; El-Hassan et al., 2013). As AM fungi is interacting with most rhizospheric organisms, the interaction studies between AM fungi and Trichoderma species has received positive attentions whose species number is still increasing (Doley and Jite, 2012a; Tanwar et al., 2013; Yabuki et al., 2014). That is why in the present investigation incorporation of AM fungus Glomus fasciculatum and Trichoderma viride (now re-classified as $T$. Asperelloides) (Mukherjee et al., 2013) was employed for biocontrol of soil-borne pathogen Sclerotium rolfsii (Sacc.). The S. rolfsii has got worldwide distribution and is capable of infecting a wide variety of crops including crucifers, grasses or 
legumes (Punja, 1985). In legumes such as groundnut (Arachis bypogaea L.) of which India is one of the chief producers in world, it causes stem-rot and is one of the major constraints in groundnut production (Manjula et al., 2004). As groundnut is important oilseed crop of India, the last two decades of increased population have doubled the consumption. Notwithstanding the growing demand of groundnut, its yield in India is becoming much less due various abiotic, biotic stresses and attack by plant pathogens (Birthal et al., 2010). Especially when the symptoms of stem-rot turn outs, its possible control by chemicals pesticides is often limited. Thus, the soil microorganism such as AM fungi and Trichoderma species seems to be a potential alternative to chemical control (Pozo and Azcon-Aguilar, 2007).

Hence, the present investigation was undertaken for evaluating the possible interaction of both $G$. fasciculatum and $T$. viride singly or in combination for biocontrol of $S$. rolfsii in local groundnut cultivar ('Western-51') in a pot culture experiment.

\section{Materials and Methods}

Plant growth, AM fungi and T. viride inoculation

Groundnut seeds (Arachis hypogaea L. local cv. 'Western51 ' - abbrev. 'W-51') were grown in pots containing sterilized soil with chemical characteristics (organic carbon $0.52 \%, \mathrm{P}_{2} \mathrm{O}_{5}$ $12.0 \mathrm{~kg} / \mathrm{acre}, \mathrm{Zn} 0.98 \mathrm{pm}, \mathrm{Cu} 3.70$ ppm, Fe 11.0 ppm, Mn $31.0 \mathrm{ppm})$. Inoculation treatments by using soil based mycorrhizal inoculum of $G$. fasciculatum (Thaxter. Gerd.) were applied below groundnut seeds during plantation at the rate of $20 \mathrm{~g}$ isolated from multiplication pots containing spores and colonized root pieces of Sorghum vulgare and talc based $T$. viride were applied at the rate $4 \mathrm{~g}$ per $\mathrm{kg}$ of seeds. Pathogen inoculum of $S$. rolfsii isolated from field was multiplied using sorghum seeds in conical flasks (incubated for 3 weeks) and applied at the rate of $5 \mathrm{~g}$ per plant after 2 weeks of planting. Sampling of plants was done after 3,6 and 9 weeks of growth for the parameters as follows: leaf, pod number, shoot, root length and fresh, dry weight. Mycorrhizal colonization was assessed by clearing the roots and staining it with trypan blue (Phillips and Hayman, 1970). The percent root colonization was determined by the gridline intersection methodology (Giovannetti and Mosse, 1980). Mycorrhizal dependency (MD) was determined by sampling dry weights as per Plenchette et al. (1983) using:

$\mathrm{MD}=$ dry weight of mycorrhizal plants-dry weight of nonmycorrhizal plants $\times 100 /$ Dry weight of mycorrhizal plants

The pots were divided into eight treatments as the following:

1) Plants were without any treatments as to serve healthy control (Control).

2) Plants were infected with $S$. rolfsii as to serve infected control $(\mathrm{C}+S$. rolfsii).

3) Plants were treated with $T$. viride as to serve Trichoderma control $(\mathrm{C}+T$. viride).

4) Plants were infected with $S$. rolfsii and treated with $T$. viride as to serve Trichoderma bio-agent $(\mathrm{C}+\mathrm{Sr}+\mathrm{Tv})$.

5) Plants were treated with $G$. fasciculatum as to serve mycorrhiza control ( $G$. fasciculatum).
6) Plants were infected with $S$. rolfsii and treated with $G$. fasciculatum as to serve mycorrhiza bio-agent (Gf+Sr).

7) Plants were treated with $G$. fasciculatum and T. viride as to serve bio-agent control (Gf+Tv).

8) Plants were infected with $S$. rolfsii and treated with $G$. fasciculatum and $T$. viride as to serve bio-agent $(\mathrm{Gf}+\mathrm{Sr}+\mathrm{Tv})$.

\section{Disease incidences}

Disease incidences were monitored on weekly basic by noting above ground signs using:

Disease incidence $(\%)=($ No. of infected plants $\times$ 100)/Total no. of plants.

\section{Biochemical and antioxidant enzyme activities}

The protein were determined as per Lowry et al. (1951), Total phenol estimation were determined according to Malick and Singh (1980). Polyphenol oxidase (PPO) was estimated as per Mahadevan and Shidhars (1982). Peroxidase (PER) was assayed as per Putter (1974). Superoxide dismutase (SOD) was assayed described by Beauchamp and Fridovich (1971).

\section{Experimental design and data analysis}

Experiment was performed using completely randomized block design (CRBD) comprising three replications with eight treatments. Inoculation comprised of $G$. fasciculatum, $T$. viride and $S$. rolfsii. Means and standard errors were calculated for three replicates. All the calculations were made by using a Microsoft Excel 2007 to analyze the data.

\section{Results}

\section{Disease incidence}

The diseases incidence was found to be significantly lowest in combined application of mycorrhiza along with Trichoderma (Gf+Sr+Tv) in presence of pathogen by $45.83 \%$ as compared to $54.17 \%$ in single application of mycorrhiza $(\mathrm{Gf}+\mathrm{Sr})$ or $59.72 \%$ Trichoderma $(\mathrm{C}+\mathrm{Sr}+\mathrm{Tv})$ and $68.06 \%$ in control ones $(\mathrm{C}+$ S. rolfsii) (Fig. 1).

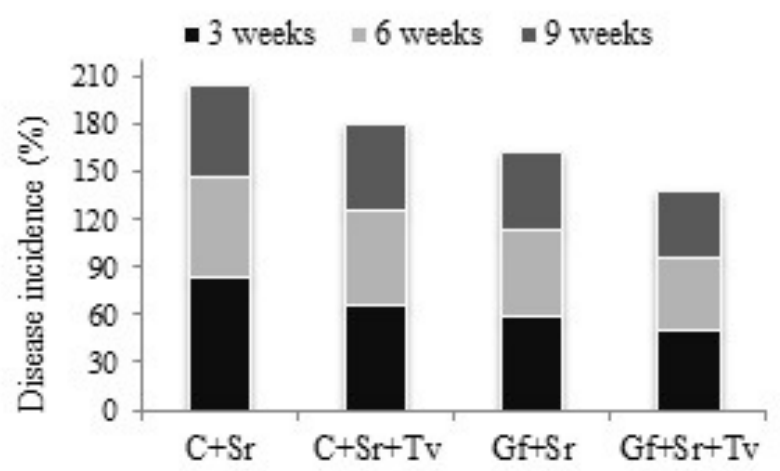

Fig 1. Incidences of disease in groundnut (W-51) due to inoculation of $G$. fasciculatum and T. viride. Mean values $(\mathrm{n}=3$ $\pm \mathrm{SD}) . \mathrm{C}+\mathrm{Sr}$ : Control $+S$. rolfsii, $\mathrm{C}+\mathrm{Sr}+\mathrm{Tv}$ : Control $+S$. rolfsii $+T$. viride, $\mathrm{Gf}+\mathrm{Sr}$ : G. fasciculatum $+S$. rolfsii, $\mathrm{Gf}+\mathrm{Sr}+\mathrm{Tv}$ : $G$. fasciculatum $+S$. rolfsii $+T$. viride 
126

\section{Mycorrbizal colonization rate}

Although AM fungi were able to colonize groundnut plant, however, there were significant differences in AM colonization percentage between control or Trichoderma or S. rolfsii treatments. The highest overall AM colonization rate was observed in only healthy AM treatment $(81.11 \%$ in Gf) as compared to healthy mycorrhiza inoculated along with Trichoderma ( $70.44 \%$ in Gf+Tv) followed by diseased mycorrhizal treatment $(61.89 \%$ in $\mathrm{Gf}+\mathrm{Sr})$ and diseased mycorrhiza inoculated along with Trichoderma (52.22\% in $\mathrm{Gf}+\mathrm{Sr}+\mathrm{Tv})($ Fig. 2).

\section{Mycorrhizaldependency}

The mycorrhizal dependency was observed to be highest in diseased mycorrhizal treatment (Gf + Sr by $63.82 \%$ ) followed by $49.88 \%$ in only mycorrhizal healthy treatment $(G$. fasciculatum), 49.61\% in diseased mycorrhiza inoculated along with Trichoderma (Gf+Sr+Tv) and $47.79 \%$ in healthy mycorrhiza inoculated along with Trichoderma (Gf+Tv) (Fig. 2).

\section{Plant growth}

The overall growth parameters showed in Table 1 such as leaf, pod number, shoot, root length and fresh, dry weight of groundnut plants in absence of pathogen showed highest growth in combination of AM fungi and Trichoderma $(\mathrm{Gf}+\mathrm{Tv})$ by single application of either AM fungi $(G$. fasciculatum) or Trichoderma (C+T. viride) or as compared to

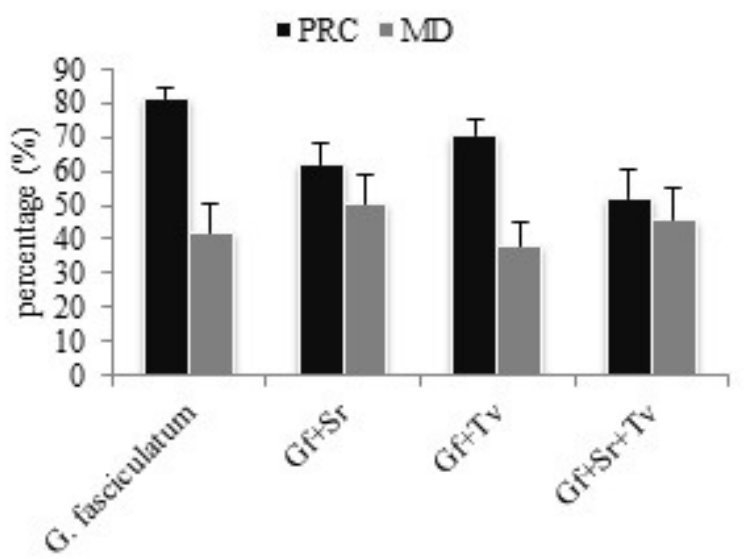

Fig 2. Percent root colonization and mycorrhizal dependency in groundnut (W-51) due to inoculation of G. fasciculatum and T. viride. Mean values $(\mathrm{n}=3 \pm \mathrm{SD})$. (PRC, percent root colonization; MD, mycorrhizal dependency). Gf+Sr: G. fasciculatum $+S$. rolfsii, Gf+Tv: $G$. fasciculatum + T. viride, $\mathrm{Gf}+\mathrm{Sr}+\mathrm{Tv}$ : G. fasciculatum + S. rolfsii + T. viride control ones. In presence of pathogen, the AM fungi inoculated groundnut plants ( $\mathrm{Gf}+\mathrm{Sr}$ ) showed better growth than only Trichoderma treatment $(\mathrm{C}+\mathrm{Sr}+\mathrm{Tv})$. However, the combined inoculation of AM fungi and Trichoderma $(\mathrm{Gf}+\mathrm{Sr}+\mathrm{Tv})$ showed higher growth than single application of either AM fungi $(\mathrm{Gf}+\mathrm{Sr})$ or Trichoderma $(\mathrm{C}+\mathrm{Sr}+\mathrm{Tv})$.

\section{Protein activity}

The protein activity showed 3-fold increase in mycorrhizal (G. fasciculatum) treatment and 2-fold in $\mathrm{Gf}+\mathrm{Sr}, \mathrm{Gf}+\mathrm{Tv}$, $\mathrm{Gf}+\mathrm{Sr}+\mathrm{Tv}$ as compared to their respective control ones. The highest activity of protein was observed in mycorrhiza inoculated along with Trichoderma in presence of pathogen $(\mathrm{Gf}+\mathrm{Sr}+\mathrm{Tv})($ Table 2).

\section{Totalphenol activity}

Total phenol activity increased more in presence of $S$. rolfsii $(\mathrm{C}+S$. rolfsii) than only Trichoderma treatment $(\mathrm{C}+T$. viride $)$. But, the activity increased due to AM fungi ( $G$. fasciculatum), Trichoderma inoculated in presence of $S$. rolfsii $(\mathrm{C}+\mathrm{Sr}+\mathrm{Tv})$, $(\mathrm{Gf}+\mathrm{Sr})$ and $(\mathrm{Gf}+\mathrm{Tv})$. However, the total phenol activity was highest in combined inoculation of mycorrhiza and Trichoderma in presence of pathogen $(\mathrm{Gf}+\mathrm{Tv}+\mathrm{Sr})$ as compared to any other treatments (Table 2).

\section{Polyphenol oxidase activity}

PPO activity significantly increased due to pathogen inoculation $(\mathrm{C}+S$. rolfsii $)$ than control or Trichoderma treatment $(\mathrm{C}+T$. viride $)$ but diseased $\mathrm{AM}$ fungi application $(\mathrm{Gf}+\mathrm{Sr})$ showed more increase than diseased Trichoderma application $(\mathrm{C}+\mathrm{Sr}+\mathrm{Tv})$. The combined $\mathrm{AM}$ fungi and Trichoderma in healthy groundnut cultivar $(\mathrm{Gf}+\mathrm{Tv})$ showed higher PPO activity than single inoculation of either $(G$. fasciculatum $)$ or $(\mathrm{C}+T$. viride $)$ treatments. However, the highest PPO activity was observed in AM fungi inoculated along with Trichoderma in presence of pathogen $(\mathrm{Gf}+\mathrm{Sr}+\mathrm{Tv})$ (Table 2).

\section{Peroxidase activity}

Significantly, highest PER activity was observed in dual inoculations of mycorrhiza inoculated along with Trichoderma in presence of pathogen $(\mathrm{Gf}+\mathrm{Sr}+\mathrm{Tv})$. The PER activity due to pathogen inoculation $(\mathrm{C}+S$. rolfsii) was higher than healthy Trichoderma inoculation $(\mathrm{C}+T$. viride). But, peroxidase activity was found to be increased two times in healthy mycorrhizal groundnut plants (G. fasciculatum) and in $(\mathrm{Gf}+\mathrm{Tv})$ treatments when compared to control ones. Also, in presence of $S$. rolfsii AM fungi inoculation $(\mathrm{Gf}+\mathrm{Sr})$ showed

Table 1. Growth parameters observed in groundnut (W-51) due to inoculation of G. fasciculatum and T. viride

\begin{tabular}{|c|c|c|c|c|c|c|}
\hline Treatments & Leaf(no.) & Shoot length $(\mathrm{cm})$ & Root length $(\mathrm{cm})$ & Fresh weight $(\mathrm{g})$ & Dry weight (g) & Pod (no.) \\
\hline Control & $63.56 \pm 5.61$ & $22.78 \pm 1.68$ & $23.33 \pm 1.65$ & $5.48 \pm 0.58$ & $2.81 \pm 0.40$ & $1.89 \pm 0.59$ \\
\hline $\mathrm{C}+\mathrm{S}$. rolfsii & $40.67 \pm 5.56$ & $18.11 \pm 2.16$ & $18.11 \pm 1.40$ & $3.91 \pm 0.83$ & $2.04 \pm 0.34$ & $0.89 \pm 0.59$ \\
\hline $\mathrm{C}+\mathrm{T}$. viride & $89.33 \pm 9.82$ & $24.33 \pm 1.36$ & $26.11 \pm 2.06$ & $7.22 \pm 0.40$ & $3.20 \pm 0.25$ & $2.89 \pm 0.74$ \\
\hline $\mathrm{C}+\mathrm{Sr}+\mathrm{Tv}$ & $65.89 \pm 5.12$ & $23.33 \pm 1.25$ & $32.33 \pm 1.25$ & $6.65 \pm 1.45$ & $2.41 \pm 0.33$ & $2.22 \pm 0.59$ \\
\hline G. fasciculatum & $138.11 \pm 5.70$ & $28.33 \pm 1.25$ & $39.44 \pm 2.27$ & $11.93 \pm 1.86$ & $5.07 \pm 0.07$ & $5.56 \pm 0.73$ \\
\hline $\mathrm{Gf}+\mathrm{Sr}$ & $65.89 \pm 4.80$ & $24.00 \pm 1.52$ & $21.67 \pm 1.97$ & $7.54 \pm 0.60$ & $4.51 \pm 0.33$ & $3.44 \pm 0.43$ \\
\hline Gf+Tv & $123.67 \pm 6.01$ & $28.78 \pm 1.68$ & $38.78 \pm 2.48$ & $10.43 \pm 1.30$ & $5.60 \pm 0.36$ & $4.56 \pm 0.59$ \\
\hline $\mathrm{Gf}+\mathrm{Sr}+\mathrm{Tv}$ & $103.33 \pm 4.52$ & $25.11 \pm 1.67$ & $34.22 \pm 2.19$ & $8.16 \pm 1.24$ & $4.81 \pm 0.34$ & $3.44 \pm 0.47$ \\
\hline
\end{tabular}


Table 2. Biochemical and antioxidant enzyme activities in leaves of groundnut (W-51) due to inoculation of $G$. fasciculatum and T. viride

\begin{tabular}{|c|c|c|c|c|c|}
\hline Treatments & Protein $^{a}$ & $\mathrm{PPO}^{\mathrm{b}}$ & Total phenols ${ }^{c}$ & $\mathrm{PER}^{\mathrm{d}}$ & $\mathrm{SOD}^{\mathrm{e}}$ \\
\hline Control & $0.056 \pm 0.008$ & $0.467 \pm 0.090$ & $0.139 \pm 0.010$ & $0.0041 \pm 0.0006$ & $2.680 \pm 0.337$ \\
\hline $\mathrm{C}+S$. rolfsii & $0.110 \pm 0.008$ & $0.769 \pm 0.175$ & $0.221 \pm 0.013$ & $0.0094 \pm 0.0010$ & $3.480 \pm 0.416$ \\
\hline $\mathrm{C}+T$. viride & $0.111 \pm 0.008$ & $0.719 \pm 0.097$ & $0.215 \pm 0.013$ & $0.0070 \pm 0.0012$ & $3.560 \pm 0.267$ \\
\hline $\mathrm{C}+\mathrm{Sr}+\mathrm{Tv}$ & $0.135 \pm 0.008$ & $0.881 \pm 0.086$ & $0.226 \pm 0.024$ & $0.0106 \pm 0.0010$ & $4.227 \pm 0.262$ \\
\hline G. fasciculatum & $0.171 \pm 0.011$ & $0.906 \pm 0.038$ & $0.280 \pm 0.010$ & $0.0107 \pm 0.0011$ & $4.507 \pm 0.305$ \\
\hline $\mathrm{Gf}+\mathrm{Sr}$ & $0.189 \pm 0.011$ & $1.022 \pm 0.043$ & $0.335 \pm 0.012$ & $0.0130 \pm 0.0011$ & $6.120 \pm 0.346$ \\
\hline Gf+Tv & $0.202 \pm 0.008$ & $0.914 \pm 0.126$ & $0.342 \pm 0.009$ & $0.0114 \pm 0.0007$ & $6.093 \pm 0.318$ \\
\hline $\mathrm{Gf}+\mathrm{Sr}+\mathrm{Tv}$ & $0.218 \pm 0.009$ & $1.111 \pm 0.097$ & $0.434 \pm 0.020$ & $0.0147 \pm 0.0008$ & $7.293 \pm 0.245$ \\
\hline
\end{tabular}

${ }^{2}$ Data were expressed as change in absorbance at $650 \mathrm{~nm}$ protein in $\mu^{-1} \mathrm{~g}^{-1}$ fresh weight

${ }^{\mathrm{b}}$ Enzyme activity were expressed as change in absorbance at $495 \mathrm{~nm} \mathrm{~min}^{-1} \mathrm{~g}^{-1}$ fresh weight

${ }^{c}$ Data were expressed as change in absorbance at $650 \mathrm{~nm} \mathrm{mg} \mathrm{g}^{-1}$ fresh weight

${ }^{\mathrm{d}}$ Enzyme activity were expressed as change in absorbance at $436 \mathrm{~nm} \mathrm{~min}^{-1} \mathrm{mg}^{-1}$ protein

${ }^{e}$ Enzyme activity were expressed as change in absorbance at $560 \mathrm{~nm}$ units $\mathrm{g}^{-1}$ fresh weight

${ }^{*}$ Mean values $(\mathrm{n}=3 \pm \mathrm{SD})$. C: Control, $\mathrm{C}+\mathrm{Sr}$ : Control+S. rolfsii, $\mathrm{C}+\mathrm{Sr}+\mathrm{Tv}$ : Control+S. rolfsii + T. viride, Gf+Sr: G. fasciculatum+S. rolfsii, Gf+Tv: G. fasciculatum + T. viride, $\mathrm{Gf}+\mathrm{Sr}+\mathrm{Tv}$ : $G$. fasciculatum $+S$. rolfsii + T. viride

more PER activity than Trichoderma treatment $(\mathrm{C}+\mathrm{Sr}+\mathrm{Tv})$ (Table 2).

\section{Superoxidase dismutase activity}

The SOD enzyme activity in presence of pathogen showed increased level with Trichoderma or AM fungi inoculations as compared with control ones. The SOD activity was more in mycorrhizal treated diseased (Gf+Sr) or in dual treatment of mycorrhiza/Trichoderma healthy (Gf+Tv) plants. But, the highest level of SOD was observed in combined application of mycorrhiza/Trichoderma in presence of pathogen (Gf+Sr+Tv) (Table 2).

\section{Discussion}

\section{Growth performance}

Pathogenic infection caused by $S$. rolfsii decreased plant growth, whereas the presence of $G$. fasciculatum in groundnut plants led to significant overall growth than non-mycorrhizal plants as illustrated in Table 1 . Also, presence $T$. viride influenced groundnut growth by increasing the overall growth parameters. But, when both $G$. fasciculatum and T. viride were present, it led to even more growth equivalent to AM fungi but not less. However, the presence of $G$. fasciculatum marked more growth than $T$. viride. Growth promotion activity by AM fungi is commonly observed as they are involved in better transportation of resources (Gracy and Bagyaraj, 2005; van der Heijden and Horton, 2009). Recent report of increase in plant root biomass has been found in barley, wheat and oats by AM fungi (Castillo, 2012). Increase in shoot, root length, fresh, dry weight, leaf area has been reported by employing AM fungi along with Trichoderma species in plants (Harman, 2006). Also, the combined effect of AM fungi, $T$. viride along with Pseudomonas fluorescens had increased growth responses in Brassica oleracea L. var. italica Plenck (Tanwar, 2013).

\section{Disease incidences}

The incidences of disease caused by pathogen $S$. rolfsii were significantly lowered by combined inoculation of both $G$. fasciculatum along with $T$. viride as compared to single inoculation of either $G$. fasciculatum or T. viride (Fig. 1). Tabin et al. (2009) reported that AM fungi can significantly inhibit damping-off in Aquilaria agalloch a Roxb. seedlings. Moreover, the colonization by AM fungi has been associated with decrease in disease incidences (Ozgonen and Erkilic, 2007; Jaime et al., 2008) but the mechanism of pathogen inhibition requires more concrete evidences. Here, the variable percentage in root colonization by AM suggests that the mechanism of pathogen resistance occurred more likely due to the competition for space and nutrients (Smith and Read, 2008). In case of Trichoderma species, they were also found to be effective against a large number of fungal phytopathogens on several economically important crops (Singh, 2006), the mechanisms has been clearly established which includes mycoparasitism, antagonistic characteristics and enzyme or metabolite secretions (Atanasova et al., 2013; Röhrich et al., 2014). As both $G$. fasciculatum and $T$. viride possesses antagonistic properties against soil-borne plant pathogens, here they showed assured inhibition against $S$. rolfsii in groundnut plants. Moreover, the synergistic interactions of AM fungi along with Trichoderma species in the plant protection against diseases have been reported (Doley and Jite, 2012a; Tanwar et al., 2013).

\section{Percent root colonization and mycorrhizal dependency}

Due to incidences of disease by $S$. rolfsii, the percent root colonization by $G$. fasciculatum was observed to be lowered in pathogenic groundnut plants $(\mathrm{Gf}+\mathrm{Sr})$ as compared to healthy AM fungi treated ( $G$. fasciculatum) ones. But, at each sampling period the healthy AM fungi along with $T$. viride treated groundnut plants $(\mathrm{Gf}+\mathrm{Tv})$ showed higher colonization of $G$. fasciculatum which shows their positive interaction attributes when compared with pathogen $S$. rolfsii $(\mathrm{Gf}+\mathrm{Sr})$ but was found to be negative in terms of percent root colonization as it decreased the colonization of $G$. fasciculatum as observed in Fig. 2. This observation marks presence of competition in between $G$. fasciculatum and $T$. viride in already stressed resources by presence of pathogen.

The mycorrhizal dependency was found to be more in pathogenic $G$. fasciculatum treatment $(\mathrm{Gf}+\mathrm{Sr})$ as compared to combined treatment of $G$. fasciculatum along with $T$. viride $(\mathrm{Gf}+\mathrm{Sr}+\mathrm{Tv})$ in presence of $S$. rolfsii which signifies major part played by $G$. fasciculatum as compared to $T$. viride in inhibition of $S$. rolfsii (Fig. 2). The present results may be correlated with disease incidences which were lower in pathogenic $G$. fasciculatum $(\mathrm{Gf}+\mathrm{Sr})$ treatment as compared to pathogenic $T$. viride treatment $(\mathrm{C}+\mathrm{Tv}+\mathrm{Sr})$. It also signifies the role of $G$. fasciculatum or $T$. viride in inhibition of pathogen during stress 
128

produced by pathogen even though the cultivar was of local hybrid quality. The higher mycorrhizal dependency rates have been observed during abiotic or biotic stresses as observed (Miranda et al., 2011; Doley and Jite, 2012b).

\section{Biochemical and antioxidant activities}

In the present experiment we observed the effect of AM fungi, Trichoderma and pathogen $S$. rolfsii inoculation on local groundnut cultivar (W-51) in bringing several changes in biochemical parameters (Table 2). Our study demonstrated increased protein levels by inoculation of $G$. fasciculatum or $T$. viride in groundnut plants and during pathogen attack. The increased protein suggests structural modifications as a defence response. The up-regulation of defence-related proteins following inoculation by AM fungi and Trichoderma species are being well documented which contributes in pathogen resistance in host plants (El-Khallal, 2007; Vargas et al., 2008).

Higher accumulation of total phenols suggested their involvement in infection sites as they assists in providing mechanical strength to host plants. Also, the phenolic compounds are known to be inhibitorier against infective agents (Kumar et al., 2010). The increased accumulation of phenolic compounds reflects increased lignification indicates possible bio-protection in plants (Ngadze, 2012). The improvement in total phenols activities by AM and Trichoderma inoculations with increased growth has been reported in common bean, Brassica oleraacea var. capitata and cotton (Al-Aksar and Rashad, 2010; Raghavendra et al., 2013).

The defence-related enzymes such as polyphenols (PPO), peroxidase (PER) and superoxide dismutase (SOD) were significantly expressed in higher levels in upon infection by $S$. rolfsii but the higher levels were observed when $G$. fasciculatum or $T$. viride were inoculated in presence of $S$. rolfsii. However, the highest levels were observed in combined application of AM fungi and Trichoderma in pathogenic ones as compared to control plants.

The increase in PPO as showed in Table 2 might have occurred for barricading the spread of pathogen S. rolfsii in groundnut plants by catalyzing oxidation of phenolics which are long known to have antimicrobial properties and it is known for inhibiting spread of pathogens (Ngadze, 2012), Mohamed et al., 2012). Thus, in the present experiment AM fungi and Trichoderma involved more directly in preventing of plant pathogen S. rolsiii.

PER are known to be involved in lignifications, oxidative polymerization of phenylpropanols to form lignins, crosslinking of cell wall and inhibition of fungal pathogens in plants (Mittler, 2002; Maksimov et al., 2014). We observed more PER in presence of pathogen than presence of $T$. viride. But, the higher PER levels were observed when treated with $G$. fasciculatum (Table 2) which is in accordance with Jaiti et al., (2008) who showed protection by increased PER activity in Phoenix dactylifera L. by AM inoculations against bayoud disease. The highest activity was showed by combined inoculations with $G$. fasciculatum/T. viride in pathogenic ones which showed their contribution in resistance of pathogen as they have potentially antifungal properties.

Against pathogen attack, the host defence system of plants generally responds by producing reactive oxygen species (ROS) at infection site such as $\mathrm{O}_{2}^{-}$and $\mathrm{H}_{2} \mathrm{O}_{2}$ (Zhou and Yao, 2004) which leads to production of jasmonic acid (JA) and salicylic acid (SA) (Occhipinti, 2011) for regulation of transcript level of defence-related genes. Various antioxidant enzymes are involved in metabolism of ROS such as SOD or PER. Among them SOD is the very first and an important scavenging enzyme involved in dismutation of superoxide radicals (Alscher et al., 2002). The up-regulation of SOD by AM fungi has reported during their association with host plant such as legumes (Lanfranco et al., 2005) which may be correlated to results obtained here (Table 2), where G. fasciculatum inoculation significantly increased the SOD activity, especially in presence of $S$. rolfsii or $T$. viride. The increased SOD activity due to $S$. rolfsii infection $(\mathrm{C}+S$. rolfsii) or Trichoderma inoculation was also observed as compared to control ones. However, the highest increase of SOD was observed with combined inoculation of $G$. fasciculatum and T. viride in presence of pathogen, where AM fungi and Trichoderma must have helped in minimizing damages caused by increased ROS. Thus, it might have provided protection in groundnut plants during oxidative stress produced by the presence of pathogen $S$. rolfsii.

Finally, the data as illustrated in Table 2 demonstrated triggering of several defence mechanisms during resistance of pathogen S. rolfsii in the leaves of local groundnut cultivar (W51) by enhanced activity of biochemical and antioxidant enzymes against pathogen $S$. rolssii for reducing possible buildup of ROS or by increasing the defence related substances against pathogen infection by single or combined inoculations of $G$. fasciculatum/T. viride. The obtained results may be significantly co-related to decreased disease incidences in groundnut plant. Also, the growth activity seemed to be increased significantly due to inoculations of $G$. fasciculatum $/ T$. viride with decrease in pathogen activity which reflects their positive attributes in application for economical biocontrol programme in environmental friendly way.

\section{References}

Alabouvette C, Olivain C, Migheli Q, Steinberg C (2009). Microbiological control of soil-borne phytopathogenic fungi with special emphasis on wilt-inducing Fusarium oxysporum. New Phytologist 184(3):529-544.

Al-Aksar AA, Rashad YM (2010). Arbuscular mycorrhizal fungi: a biocontrol agent against common bean Fusarium root rot disease. Plant Pathology Journal 9(1):31-38.

Alscher RG, Erturk N, Heath LS (2002). Role of superoxide dismutases (SODs) in controlling oxidative stress in plants. Journal of Experimental Botany 53(372):1331-1341.

Atanasova L, Crom SL, Gruber S, Coulpier F, Seidl-Seiboth V, Kubicek CP, Druzhinina IS (2013). Comparative transcriptomics reveals different strategies of Trichoderma mycoparasitism. BMC Genomics 14:121.

Beauchamp C, Fridovich I (1971). Superoxide Dismutase: improved assays and an assay applicable to acrylamide gels. Analytical Biochemistry 44(1):276-286.

Bhale UN, Wagh PM, Rajkonda JN (2013). Antagonistic confrontation of Trichoderma spp against fruit rot pathogens on Sapodilla (Manilkara zapota L.). Journal of Yeast Fungal Research 4(1):5-11. 
Birthal PS, Parthasarathy Rao P, Nigam SN, Bantilan MCS, Bhagavatula S (2010). Groundnut and Soybean Economies in Asia. In: Facts, Trends and Outlook, International Crops Research Institute for the Semi-Arid Tropics. Patancheru 502 324, Andhra Pradesh, India pp 92.

Cameroon DD, Neal AL, van Wees SCM, Ton J (2013). Mycorrhizainduced resistance: more than the sum of its parts? Trends in Plant Science 18(10):539-545.

Castillo CG, Puccio F, Morales D, Borie F, Sieverding E (2012). Early arbuscular mycorrhiza colonization of wheat, barley and oats in andosols of southern Chile. Journal of Soil Science and Plant Nutrition 12(3):511-524.

Doley K, Jite PK (2012a). Efficacy of Glomus fasciculatum and Trichoderma viride for biological control of stem-rot caused by pathogen Sclerotium rolfsii in groundnut. Journal Advances in Plant Sciences 25:647-652.

Doley K, Jite PK (2012b). Effect of arbuscular mycorrhizal fungi on growth of groundnut and disease caused by Macrophomina phaseolina. Journal of Experimental Sciences 3(9):46-50.

El-Hassan SA, Gowen SR, Pembroke B (2013). Use of Trichoderma hamatum for biocontrol of Lentil vascular wilt disease: efficacy, mechanisms of interaction and future prospects. Journal of Plant Protection Research 53:12-26.

El-Khallal SM (2007). Induction and modulation of resistance in tomato plants against Fusarium wilt disease by bioagent fungi (arbuscular mycorrhiza) and/or hormonal elicitors (jasmonic acid and salicylic acid): 2-Changes in the antioxidant enzymes, phenolic compounds and pathogen related- proteins. Australian Journal of Basic and Applied Sciences 1:717-732.

Ene M, Alexandru M, Sesan TE (2010). Microscopy and detection by PCR (Polymerase chain reaction). In: Sesan TE (Ed). Two methods for confirmatory assay on arbuscular mycorrhizal fungi infection. Romanian approaches in the frame of European research, Ed. Universităţii din Bucureşti pp 83-93.

Giovannetti M, Mosse B (1980). An evaluation of techniques for measuring vesicular-arbuscular mycorrhizal infection in roots. New Phytologist 84:489-500.

Gracy L, Sailo, Bagyaraj DJ (2005). Influence of different AM fungi on growth, nutrition and forskolin content of Coleus forskoblii. Mycological Research 109(7):795-798.

Harman GE (2006). Overview of mechanisms and uses of Trichoderma spp. Phytopathology 96(2):190-194.

Hohmann P, Jones EE, Hilla RA, Stewart A (2011). Understanding Trichoderma in the root system of Pinus radiate: associations between rhizosphere colonisation and growth promotion for commercially grown seedlings. Fungal Biology 115(8):759-767.

Jaime MDLA, Hsiang T, McDonald MR (2008). Effects of Glomus intraradices and onion cultivar on Allium white rot development in organic soils in Ontario. Canadian Journal of Plant Pathology 30(4):543-553.

Jaiti F, Meddich A, El-Hadrami I (2008). Effectiveness of arbuscular mycorrhizal fungi in the protection of date palm (Phoenix dactylifera L.) against Bayoud disease. Physiological and Molecular Plant
Pathology 71(4-6):166-173.

Kumar A, Mali PC, Manga VK (2010) Changes of some phenolic compounds and enzyme activities on infected pearl millet caused by Sclerospora graminicola. International Journal of Plant Physiology and Biochemistry 2(1):6-10.

Lanfranco L, Novero M, Bonfante P (2005). The mycorrhizal fungus Gigaspora margarita possesses a $\mathrm{CuZn}$ superoxide dismutase that is up-regulated during symbiosis with legume hosts. Plant Physiology 137:1319-1330.

Lowry OH, Rosenbrough NK, Far AL, Randall RJ (1951). Protein measurement with the Folin phenol reagent. Journal of Biological Chemistry 193(1):265-275.

Mahadevan A, Shridhar R (1982). Methods in physiological plant pathology, second edition; Sivakami publication, Madras pp 153155.

Maksimov I, Troshina N, Surina O, Cherepanova E (2014). Salicylic acid increases the defense reaction against bunt and smut pathogens in wheat calli. Journal of Plant Interactions 9(1):306-314.

Malick CP, Singh MB (1980). Plant enzymology and histo enzymology. Kalyani publishers, New Delhi pp 286.

Manjula K, Krishna GK, Girish AG, Singh SD (2004). Combined application of Pseudomonas fluorescens and Trichoderma viride has an improved biocontrol activity against stem rot in groundnut. Journal of Plant Pathology 20:75-80.

Meyer A, Grote R, Polle A, Butterbech-Bahl K (2010). Simulating mycorrhizal contribution to forest $\mathrm{C}$ - and $\mathrm{N}$ cycling - the MYCOFON model. Plant and Soil 327(1-2):493-517.

Miranda D, Fischer G, Ulrichs C (2011). The influence of arbuscular mycorrhizal colonization on the growth parameters of Cape gooseberry (Physalis peruviana L.) plants grown in a saline soil. Journal of Soil Science and Plant Nutrition 11(2):18-30.

Mittler R (2002). Oxidative stress, antioxidants and stress tolerance. Trends in Plant Science 7(9):405-410.

Mohamed H, EL-Hady AA, Mansour M, El-Rheem, El-Samawaty A (2012). Association of oxidative stress components with resistance to flax powdery mildew. Tropical Plant Pathology 37(6):386-392.

Mukherjee AK, Sampath Kumar A, Kranti S, Mukherjee PK (2014). Biocontrol potential of three novel Trichoderma strains: isolation, evaluation and formulation. 3 Biotech 4:275-281.

Mukherjee PK, Mukherjee AK, Kranthi S (2013). Reclassification of Trichoderma viride (TNAU), the most widely used commercial biofungicide in India, as Trichoderma asperelloides. Open Biotechnological Journal 7:7-9.

Ngadze E, Icishahayo D, Coutinho TA, van der Waals JE (2012). Role of polyphenol oxidase, peroxidase, phenylalanine ammonia lyase, chlorogenic acid, and total soluble phenols in resistance of potatoes to soft rot. Plant Disease 96(2):186-192.

Occhipinti A, Zebelo SA, Capuzzo A, Maffei M, Gnavi G (2011). Chrysolina herbacea modulates jasmonic acid, cis-(+)-12oxophytodienoic acid, (3R,7S)-jasmonoyl-l-isoleucine, and salicylic acid of local and systemic leaves in the host plant Mentha aquatica. Journal of Plant Interactions 6:99-101.

Ozgonen H, Erkilic A (2007). Growth enhancement and phytophtho- 
130

ra blight (Phytophthora capsici L ) control by arbuscular mycorrhizal fungal inoculation in pepper. Crop Protection 26(11):1682-1688.

Phillips JM, Hayman DS (1970). Improved procedure for cleaning roots and staining parasitic and vesicular arbuscular mycorrhizal fungi for rapid assessment of infection. Transactions of the British Mycological Society 55(1):158-160.

Plenchette C, Fortin JA, Furlan V (1983). Growth responses of several plant species to mycorrhizae in a soil of moderate P fertility. I. Mycorrhizal dependency under field conditions. Plant and Soil 70:199-209.

Pozo MJ, Azcon-Aguilar C (2007). Unraveling mycorrhiza-induced resistance. Current Opinion in Plant Biology 10(4):393-398.

Punja ZK (1985). The biology, ecology, and control of Sclerotium rolfsii. Annual Review of Phytopathology 23:97-127.

Putter J (1974). Peroxidase. In: Bergmeyer HU (Ed). Methods of enzymatic analysis, Academic Press, New York, USA pp 567-1124.

Raghavendra VB, Siddalingaiah L, Sugunachar NK, Nayak C, Ramachandrappa NS (2013). Induction of systemic resistance by biocontrol agents against bacterial blight of cotton caused by Xanthomonas campestris pv. Malvacearum. International Journal of Phytopathology 2(1):59-69.

Röhrich RC, Jaklitsch WM, Voglmayr H, Iversen A, Vilcinskas A, Nielsen KF, Thrane U, von Döhren H, Brückner H, Degenkolb T (2014). Front line defenders of the ecological niche! Screening the structural diversity of peptaibiotics from saprotrophic and fungicolous Trichoderma/Hypocrea species. Fungal Diversity 69(1):117-146.

Singh HB (2006). Achievements in biological control of diseases with antagonistic organisms at National Botanical Research Institute, Lucknow. In: Ramanujan B, Rabindra RJ (Ed). Current Status of Biological Control of Plant Diseases using Antagonistic Organisms in India. Technical Document, Project Directorate of Biological Control, Bangalore pp 329-340.

Smith SE, Read DJ (2008). Mycorrhizal Symbiosis, Academic, London.
Smith SE, Smith FA (2012). Fresh perspective on the roles of arbuscular mycorrhizal fungi in plant nutrition and growth. Mycologia 104:113.

Tabin T, Arunachalam A, Shrivastava K, Arunachalam K (2009). Effect of arbuscular mycorrhizal fungi on damping-off disease in Aquilaria agallocha Roxb. seedlings. Tropical Ecology 50(2):243-248.

Tanwar A, Aggarwal A, Kaushish S, Chauhan S (2013). Interactive Effect of AM Fungi with Trichoderma viride and Pseudomonas fluorescens on Growth and Yield of Broccoli. Plant Protect Science 49:137-145.

van der Heijden MGA, Horton TR (2009). Socialism in soil? The importance of mycorrhizal fungal networks for facilitation in natural ecosystems. Journal of Ecology 97(6):1139-1150.

Vargas WA, Djonović S, Sukno SA, Kenerley CM (2008). Dimerization controls the activity of fungal elicitors that trigger systemic induced resistance in plants. Journal of Biological Chemistry 283(28):19804-19815.

Verbruggen E, Marcel GA, van der Heijden MGA, RilligMC, Kiers ET (2013). Mycorrhizal fungal establishment in agricultural soils: factors determining inoculation success. New Phytologist 197:1104-1109.

Yabuki T, Miyazaki K, Okuda T (2014) Japanese species of the Longibrachiatum clade of Trichoderma. Mycoscience 55:196-212.

Zhou HZ, Yao Q (2004). Localized and systemic increase of phenols in tomato roots induced by Glomus versiforme inhibit Ralstonia Solanacearum. Journal of Phytopathology 152(10):537-546.

Ziedan EH, Elewa IS, Mostafa MH, Sahab AF (2011). Applications of mycorrhizae for controlling root rot diseases of sesame. Journal of Plant Protection Research 51(4):354-361. 